\title{
Short term influence of mechanical factors on regional musculoskeletal pain: a study of new workers from 12 occupational groups
}

\author{
E S Nahit, G J Macfarlane, C M Pritchard, N M Cherry, A J Silman
} Abstract
Objectives-To determine the influence of
short term exposure to mechanical fac-
tors on regional musculoskeletal pain.
Methods-Full time newly employed work-
ers were recruited from 12 occupational
groups and information collected by ques-
tionnaire. Subjects indicated on a blank
body manikin any low back, shoulder, wrist
or forearm or both, or knee pain which had
occurred during the past month and had
lasted more than 1 day. Data were also col-
lected with a previously validated question-
naire on working postures, manual
handling activities, and repetitive move-
ments of the upper limb. The relations
between mechanical factors and each area
of pain were calculated as odds ratios
(ORs) with $95 \%$ confidence intervals ( $95 \%$
CIs). Adjustment was made for age and
Sex. sex.

Results-1081 subjects (median age 23; interquartile range 20-27) were recruited to the study (a participation rate of $91 \%$ ). $261(24 \%)$ reported low back pain, 221 $(20 \%)$ shoulder pain, $93(9 \%)$ wrist or forearm pain, and $222(21 \%)$ knee pain. Several specific manual handling activities were found to be associated with low back, shoulder, and knee pain. Carrying weights of more than $50 \mathrm{lbs}(23 \mathrm{~kg})$ on one shoulder was the factor which was most strongly associated with low back pain (OR 2.4 (95\% CI 1.5 to 3.8)), shoulder pain (OR 3.1 (95\% CI 1.9 to 4.8$)$ ), and knee pain (OR 3.5 (95\% CI 2.2 to 5.5)), whereas forearm pain was most strongly associated with repetitive movements of the wrists (OR 1.8 (95\% CI 1.04 to 3.1)). By contrast very few postures were associated with regional pain, although bending forwards in an uncomfortable position for at least 15 minutes was associated with shoulder pain (OR $1.6(95 \%$ CI 1.2 to 2.2$)$ ) and kneeling for at least 15 minutes was associated with knee pain (OR 1.8 (95\% CI 1.2 to 2.6)). Exposure to mechanical factors was most strongly associated with pain at multiple sites rather than with pains in individual regions.

Conclusions-Even among workers with only short term exposure to mechanical factors, musculoskeletal pain is increased. (Occup Environ Med 2001;58:374-381)

Keywords: epidemiology; manual handling; questionnaire
There is strong evidence to suggest a link between musculoskeletal injury and work. As an example, a recent review ${ }^{1}$ identified 39 studies which examined the relation between mechanical factors and shoulder problems. Overall a positive association between shoulder problems and both highly repetitive work and repeated or sustained postures was found. In the same review, more than 40 studies were identified which examined the relation between mechanical factors and back problems. These reported evidence that back problems were related to heavy physical work, lifting, forceful movements, awkward postures, and whole body vibration.

Although there have been many such studies which have considered the influence of mechanical work related factors on musculoskeletal pain, these are plagued by several problems that affect their interpretation. One concern is that most studies have focused on a single occupational group. Consequently comparisons between studies may be misleading as exposure measurements for different occupational groups may not be standardised, and furthermore, there may be interactions between mechanical factors and other aspects of a particular occupation. In one attempt to combine findings from different studies with the aim of evaluating the association of occupational exposures with diseases of the shoulder and neck 21 studies were identified. Most of these compared only two occupational groups: the occupational group of interest and a referent group. Only one of the studies included a diverse range of occupational groups. ${ }^{3}$ In a more recent study which considered multiple occupations, ${ }^{4}$ bent or twisted postures were found to have an independent effect on sciatic pain among longshore workers, earth moving operators, carpenters, and office workers.

Secondly, most studies have not taken into account the healthy worker effect-namely, that those who are able to withstand exposure to a particular factor are more likely to continue to be exposed. As an example, in a study which focused specifically on people who had left the fish processing industry, ${ }^{5}$ it was found that a high proportion reported pain in the neck and upper limbs as the reason for leaving. In another study, ${ }^{6}$ bricklayers aged over 40 who had left the job had a higher occurrence of low back troubles before leaving than those who stayed in the job. Furthermore in pairs of bricklayers of the same age but with different durations of employment, there was a decline of ill health complaints and impairments with increased duration of employment. Similarly, in a large community based study, ${ }^{7}$ it was found 
that those with the longest exposure to lifting or moving weights had a lower risk of low back pain than those with a shorter exposure.

A third shortcoming of most studies is that most have focused on a single region of pain. Different risk factors have been identified for each region of pain. As an example, heavy physical work has been found to be associated with low back problems, ${ }^{89}$ whereas repetitive and static work has been found to be associated with shoulder pain. ${ }^{10}{ }^{11}$ Furthermore, some studies have found that a particular mechanical exposure is protective for one anatomical region, whereas others have found the same exposure to act as a risk factor in its relation with another region. Indeed sitting has been found to be protective of low back pain ${ }^{12-14}$ but harmful to shoulder pain. ${ }^{15}$ As studies are so diverse in the populations and methods used, it is difficult to determine whether such differences between risk factors identified for individual body regions are genuine or whether they simply reflect variations in study methods. One of the few studies which examined pain at several sites, ${ }^{16}$ found that among postal workers occupational activities were specific for musculoskeletal site involved. For example, prolonged heavy lifting was found to be associated with hip pain, and among men only, with low back pain. Working with hands raised was found to be associated with an increased risk of shoulder pain. Further evidence of a specific effect was provided in a study of factory workers. ${ }^{17}$ Repetitive work was associated with neck and shoulder pain, seated work with neck and shoulder pain, and dynamic postures of the wrist and hand were associated with wrist and hand pain.

To overcome these problems, using standardised methods we investigated the role of mechanical factors on the occurrence of musculoskeletal pain syndromes at several anatomical sites in newly employed workers, across a wide range of occupational groups.

\section{Subjects and methods}

The study was a cross sectional survey of workers within the early stages of employment. Details of mechanical exposures and the occurrence of musculoskeletal pain were collected from a questionnaire.

SUBJECTS

Twelve occupational groups were selected as the sampling frame for the study. These included a broad range of occupations and industries where high rates of musculoskeletal disorders were anticipated. All workers who were employed for at least 20 hours a week were eligible to take part, and for practical purposes, workplaces had to contribute a minimum of 40 workers employed within the past 12 months, and have a stable workforce where most of the workers remained employed for at least 3 years.

Community surveys suggest a conservative 1 month prevalence of $20 \%$ for most regional pain symptoms. ${ }^{18} 19$ For a mechanical factor with a prevalence of $10 \%$ among the pain free subjects, it was estimated that 1000 subjects were required to have $80 \%$ power to detect a doubling in risk of pain associated with such a factor (significance level 0.05).

\section{METHODS}

Data were collected by a self completed questionnaire. This included questions relating to demographic details, physical work load, ${ }^{20}$ and musculoskeletal pain. For the musculoskeletal pain, subjects were asked to shade on a blank body manikin any pain experienced during the past month which had lasted for longer than 24 hours.

Questions which related to physical work load had been validated by comparing self reports with a direct observational method of 123 randomly selected employees from six occupational settings. ${ }^{20}$ The accuracy was assessed with a sensitivity and specificity analysis based on the assumption that the observational method represented the standard. Details of posture, repetitive movements of the upper limb, and manual handling activities were collected. The following working postures were included: sitting, standing, driving, kneeling, squatting, bending forwards in an uncomfortable position, stretching downwards below knee level, and working with hands above shoulder level. For each posture information was asked on the duration of time spent in the posture during the person's last working day. Subjects were required to select one of four categories: less than 15 minutes, 15 minutes to less than 2 hours, 2 hours to less than 4 hours, and 4 hours or more.

Four questions were included which related to repetitive movements of the wrists and the arms. Workers were asked to specify the tasks which necessitated such movements, the side of the body used, the frequency of the repeated movement in any 10 minute period, and the duration of time spent during the last working day carrying out this repetitive activity.

The rest of the physical work load questionnaire related to manual handling activities comprising lifting or carrying weights with one hand, lifting or carrying weights with two hands, carrying weights on one shoulder, lifting weights at or above shoulder level, and pushing and pulling weights. Information was requested on: the side of the body used (where applicable), the average weight involved, the heaviest weight involved, frequency per hour (recorded on a four point scale) and duration during the last working day (recorded on a four point scale). To assist the subjects in their estimation of weights, a visual aid was provided which consisted of a scale along which various household objects were placed according to their weight. Two scales were provided, one metric (kg), the other imperial (lb). The scales were placed directly above one another so that conversion from metric measures to imperial measures could be made. Subjects had to indicate the weight on a similar visual analogue scale. This ranged from $0-100 \mathrm{lb}(0-45 \mathrm{~kg})$ for all manual handling activities with the exception of pushing and pulling, which used a range of 0-200 lb (0-91 kg). 


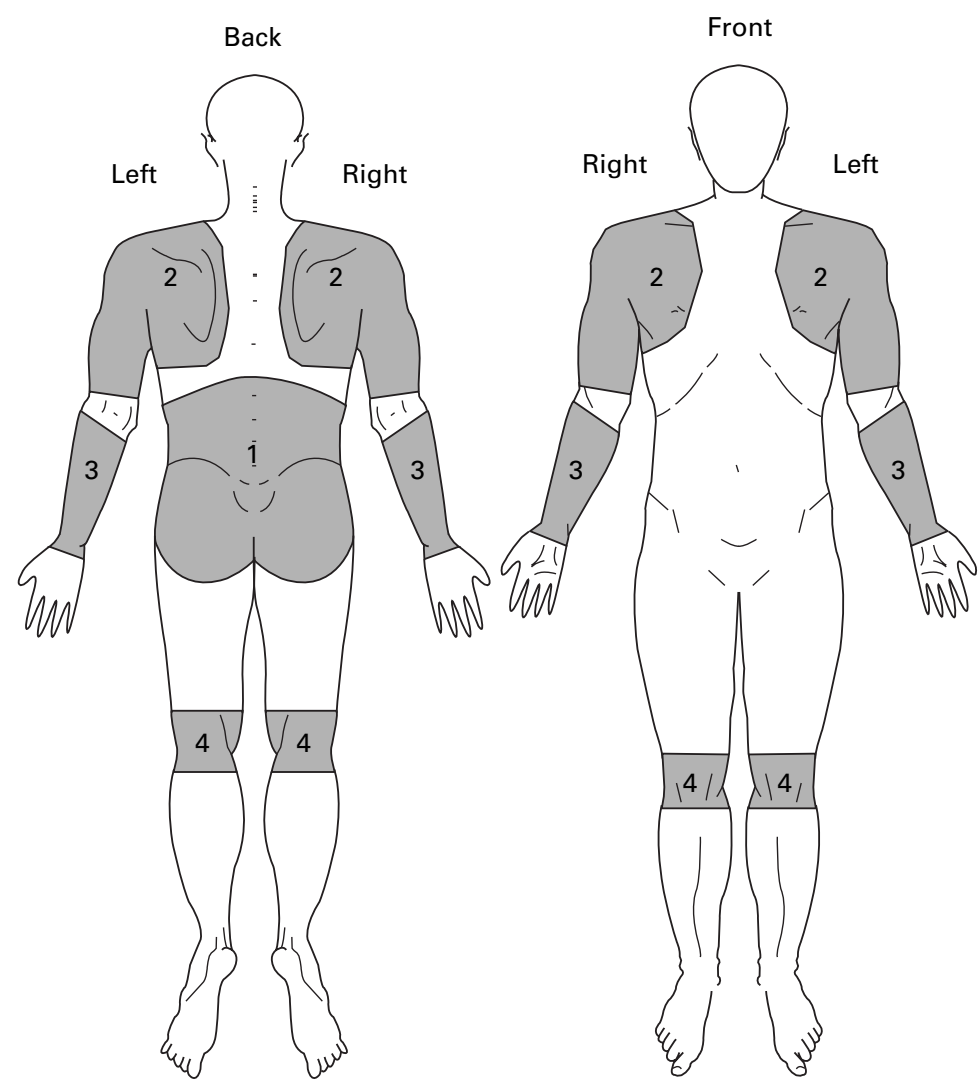

Figure 1 Definition of regional pain. 1=Low back pain; $2=$ shoulder pain; 3=wrist or forearm pain; $4=$ knee pain.

A research worker explained the study to the subject and offered assistance if necessary with completion of the questionnaire. The study was introduced as a study of health in the workplace and the specific outcomes of interest were not mentioned.

\section{STATISTICAL ANALYSIS}

Postures and repetitive movements were categorised in terms of duration, and manual handling activities were categorised in terms of weight involved. For each activity, the responses were dichotomised so that a minimum of 100 subjects were included in the more extreme category. Low back pain, shoulder pain, wrist or forearm or both, and knee pain shaded on the blank manikin were defined according to the areas shown in figure 1. The association for each of the exposures and the reporting of pain was calculated. Only those
Table 2 Prevalence (n (\%)) of musculoskeletal pain by site

\begin{tabular}{lclc}
\hline Area of pain & $\begin{array}{l}\text { Men } \\
(n=734)\end{array}$ & $\begin{array}{l}\text { Women } \\
(n=347)\end{array}$ & $\begin{array}{l}\text { Total } \\
(n=1081)\end{array}$ \\
\hline Low back & $189(25.8)$ & $72(20.8)$ & $261(24.1)$ \\
Shoulder & $176(24.0)$ & $45(13.0)$ & $221(20.4)$ \\
Wrist or forearm & $67(9.1)$ & $26(7.5)$ & $93(8.6)$ \\
Knee & $175(23.8)$ & $47(13.5)$ & $222(20.5)$ \\
\hline
\end{tabular}

associations which were considered to be biologically credible were calculated-for example, any relation between repetitive wrist movements and low back pain was not explored. Associations were expressed as odds ratios (ORs) (95\% confidence intervals (95\% CIs)), adjusted for age and sex.

For each individual area of pain, those factors for which there were significantly increased ORs of greater than 1.5 were considered. The subjects were divided into those exposed to zero, one, two, three, and four or more factors. Associations between the number of exposures were expressed relative to exposure to none of the factors and adjusted for age and sex. A $\chi^{2}$ test for trend was carried out to establish whether there was a trend with increased number of exposures.

\section{Results}

A total of 1081 workers took part in the study (table 1), with an overall response rate of $91 \%$. This varied across occupational groups, with workers who were allocated time to complete the questionnaire during normal working hours more likely to respond. The lowest response was found among forestry workers, many of whom were working on placements as part of their study and had to be contacted individually by one of the research workers.

The study participants were young with a median age of 23 , of whom $68 \%$ were male. For most of these workers, this was their first full time permanent job, with only half of the subjects ever having worked before. The median duration of employment reported by the subjects was 8 months. The shipbuilders and army infantry were the youngest on average, the postal workers and retail workers the oldest. The employers reported that before the start of data collection no one from the target population had left any one of the selected occupational groups because of musculoskeletal pain.

The overall prevalences of low back pain, shoulder pain, and knee pain (table 2) were

Table 1 Characteristics of subjects

\begin{tabular}{|c|c|c|c|c|c|c|}
\hline Occupation & Source of sample & $\begin{array}{l}\text { Surveyed } \\
(n)\end{array}$ & $\begin{array}{l}\text { Participated } \\
\text { (n) }\end{array}$ & $\begin{array}{l}\text { Response rate } \\
(\%)\end{array}$ & $\begin{array}{l}\text { Women } \\
(n(\%))\end{array}$ & $\begin{array}{l}\text { Age } \\
\left.\text { (median, } I Q R^{\star}\right)\end{array}$ \\
\hline Firefighters & All new recruits from four counties & 166 & 163 & 98 & $1(0.6)$ & $25(23-27)$ \\
\hline Retail workers & All workers at a newly opened store & 153 & 114 & 75 & $73(64.0)$ & $35(26-43)$ \\
\hline Shipbuilders & All new apprentices from a sample of courses & 113 & 113 & 100 & $2(1.8)$ & $17(16-18)$ \\
\hline Dentists & All final year students from two universities & 117 & 112 & 96 & $55(49.1)$ & $23(22-24)$ \\
\hline Army infantry & Two samples of 50 new recruits & 100 & 100 & 100 & $0(0)$ & $18(17-20)$ \\
\hline Army officers & Three samples of 34 new recruits & 102 & 96 & 94 & $8(8.3)$ & $23(22-24)$ \\
\hline Nurses & All final year students from one university & 106 & 87 & 82 & $81(93.1)$ & $24(22-27)$ \\
\hline Podiatrists & All final year students from two universities & 84 & 79 & 94 & $64(81.0)$ & $24(21-30)$ \\
\hline Postal workers & All workers at a newly opened branch & 83 & 70 & 84 & $6(8.6)$ & $34(31-41)$ \\
\hline Army clerks & All new recruits on three courses & 70 & 69 & 99 & $47(68.1)$ & $20(19-23)$ \\
\hline Police officers & All new recruits on three courses & 44 & 44 & 100 & $8(18.2)$ & $27(24-29)$ \\
\hline Forestry workers & All final year students from one college & 48 & 34 & 71 & $2(5.9)$ & $22(20-23)$ \\
\hline Total & & 1186 & 1081 & 91 & $347(32.1)$ & $20(23-27)$ \\
\hline
\end{tabular}

^Interquartile range (25th-75th percentile). 
Table 3 Prevalence of pain by occupational group

\begin{tabular}{lrcccc}
\hline $\begin{array}{l}\text { Occupational } \\
\text { group }\end{array}$ & $n$ & $\begin{array}{l}\text { Low back pain } \\
n(\%)\end{array}$ & $\begin{array}{l}\text { Shoulder pain } \\
n(\%)\end{array}$ & $\begin{array}{l}\text { Wrist or } \\
\text { forearm painn (\%) }\end{array}$ & $\begin{array}{l}\text { Knee pain } \\
n(\%)\end{array}$ \\
\hline Firefighters & 163 & $34(21)$ & $38(23)$ & $19(12)$ & $39(24)$ \\
Retail workers & 114 & $29(25)$ & $20(18)$ & $11(10)$ & $16(14)$ \\
Shipbuilders & 113 & $22(19)$ & $13(12)$ & $13(12)$ & $8(7)$ \\
Dentists & 112 & $26(23)$ & $17(15)$ & $7(6)$ & $14(13)$ \\
Army infantry & 100 & $41(41)$ & $50(50)$ & $3(3)$ & $38(38)$ \\
Army officers & 96 & $32(33)$ & $36(38)$ & $16(17)$ & $42(44)$ \\
Nurses & 87 & $17(20)$ & $11(13)$ & $4(5)$ & $8(9)$ \\
Podiatrists & 79 & $17(22)$ & $6(8)$ & $10(13)$ & $13(16)$ \\
Postal workers & 70 & $14(20)$ & $14(20)$ & $1(1)$ & $13(19)$ \\
Army clerks & 69 & $12(17)$ & $4(6)$ & $4(6)$ & $6(14)$ \\
Police & 44 & $5(11)$ & $7(16)$ & $2(5)$ & $7(21)$ \\
Forestry workers & 34 & $12(35)$ & $5(15)$ & $3(9)$ & $222(21)$ \\
Total & 1081 & $261(24)$ & $221(20)$ & $93(9)$ & \\
\hline
\end{tabular}

very similar $(24 \%, 20 \%$, and $21 \%$ respectively). Wrist and forearm pain was less common (prevalence 9\%). Men reported more pain in each of the four regions (table 2). The prevalence of pain for each region varied between the different occupational groups (table 3). The army officers reported the highest level of wrist or forearm (17\%) and knee pain $(44 \%)$ and the second highest level of shoulder pain (38\%). Army infantry reported the highest level of low back $(41 \%)$ and shoulder pain (50\%) and the second highest level of knee pain $(38 \%)$. Forestry workers reported a high level of low back pain (35\%).

There were a significantly increased OR of low back pain associated with carrying on one shoulder (table 4). Other increased ORs were broadly similar in strength, but we arbitrarily selected those ORs which were greater than 1.5 and were significant for the next stage of the analysis. These included lifting at least $25 \mathrm{lb}$ $(11 \mathrm{~kg})$ with one hand and lifting at least $50 \mathrm{lb}$ $(23 \mathrm{~kg})$ with two hands. Those with low back pain had a threefold increased OR of exposure to all three of the mechanical factors (table 5) compared with those without low back pain (OR 3.3 (95\% CI 1.4 to 7.7 )).

The same three mechanical factors as for low back pain also had the strongest associations with shoulder pain (table 6). There was indeed a stronger relation between shoulder pain and these mechanical factors than there was for low back pain, with additional influences (using the same arbitrary rules as for low back pain): lifting at or above shoulder level, pulling, and bending forwards in an uncomfortable position. Those with shoulder pain had a fourfold increased OR of exposure to at least four out of six of these mechanical factors (table 7) compared with those without shoulder pain (OR 4.3 (95\% CI 2.4 to 7.9 )).

In common with low back pain and shoulder pain, knee pain was again associated with lifting with one hand, lifting with two hands, and carrying weights on one shoulder (table 8). Also, lifting at or above shoulder level and kneeling were associated with knee pain. Those with knee pain had a fourfold increased OR of exposure to at least four of these factors (table 9) compared with those without knee pain (OR 4.4 (95\% CI 2.0 to 9.4$)$ ).

Only repetitive wrist movements were associated with wrist or forearm pain (table 10). Those who carried out repetitive wrist movements for at least 4 hours during their last working day had an $80 \%$ increased OR of reporting wrist or forearm pain compared with those who carried out these tasks for less than 4 hours. Also, this relation was highly specific with only $14 \%$ of people without forearm pain reporting repetitive wrist movements.

We were concerned that these apparent associations may be explained, in part, by other exposures which had not been measured. Thus there may be factors specific to individual occupational groups. To consider this we assessed whether the associations persisted after adjusting for occupational group. After this only one relation with low back pain was substantially attenuated: carrying more than 50 lbs on one shoulder (OR 1.8 (95\% CI 1.02 to 3.0)) but this relation still remained significant. There were, however, more effects on the associations with shoulder pain. The relation with lifting more than $25 \mathrm{lb}(11 \mathrm{~kg})$ with one hand was also attenuated (OR 1.5 (95\% CI 0.97 to

Table 4 Relations between occupational load and low back pain

\begin{tabular}{|c|c|c|c|c|}
\hline Exposure & & Total & $\begin{array}{l}\text { Low back pain } \\
n(\%)\end{array}$ & $\begin{array}{l}\text { Adjusted for age and sex } \\
\text { OR }(95 \% \text { CI })\end{array}$ \\
\hline Lifting $>25 \mathrm{lb}(11 \mathrm{~kg})$ with one hand: & $\begin{array}{l}\text { Yes } \\
\text { No }\end{array}$ & $\begin{array}{l}228 \\
832\end{array}$ & $\begin{array}{r}76(33) \\
181(22)\end{array}$ & $1.7(1.2$ to 2.4$)$ \\
\hline Lifting $>50 \mathrm{lb}(23 \mathrm{~kg})$ with two hands & $\begin{array}{l}\text { Yes } \\
\text { No }\end{array}$ & $\begin{array}{l}103 \\
950\end{array}$ & $\begin{array}{r}35(34) \\
221(23)\end{array}$ & $1.6(1.01$ to 2.5$)$ \\
\hline Carrying $>50 \mathrm{lb}(23 \mathrm{~kg})$ on one shoulder & $\begin{array}{l}\text { Yes } \\
\text { No }\end{array}$ & $\begin{array}{l}100 \\
962\end{array}$ & $\begin{array}{r}44(44) \\
217(23)\end{array}$ & $2.4(1.5$ to 3.8$)$ \\
\hline Lift $>25 \mathrm{lb}(11 \mathrm{~kg})$ at or above shoulder level & $\begin{array}{l}\text { Yes } \\
\text { No }\end{array}$ & $\begin{array}{l}146 \\
911\end{array}$ & $\begin{array}{r}44(30) \\
210(23)\end{array}$ & $1.3(0.9$ to 2.0$)$ \\
\hline Pulling $>50 \mathrm{lb}(23 \mathrm{~kg})$ & $\begin{array}{l}\text { Yes } \\
\text { No }\end{array}$ & $\begin{array}{l}168 \\
892\end{array}$ & $\begin{array}{r}50(30) \\
206(23)\end{array}$ & $1.5(1.03$ to 2.2$)$ \\
\hline Pushing $>100 \mathrm{lb}(45 \mathrm{~kg})$ & $\begin{array}{l}\text { Yes } \\
\text { No }\end{array}$ & $\begin{array}{l}136 \\
921\end{array}$ & $\begin{array}{r}39(29) \\
217(24)\end{array}$ & $1.5(0.9$ to 2.3$)$ \\
\hline Standing $\geqslant 4 \mathrm{~h}$ & $\begin{array}{l}\text { Yes } \\
\text { No }\end{array}$ & $\begin{array}{l}192 \\
880\end{array}$ & $\begin{array}{r}55(29) \\
205(23)\end{array}$ & $1.4(0.97$ to 2.0$)$ \\
\hline Driving $\geqslant 15$ minutes & $\begin{array}{l}\text { Yes } \\
\text { No }\end{array}$ & $\begin{array}{l}101 \\
976\end{array}$ & $\begin{array}{r}24(24) \\
236(24)\end{array}$ & $1.2(0.7$ to 2.0$)$ \\
\hline Stretching down below knee level $\geqslant 15$ minutes & $\begin{array}{l}\text { Yes } \\
\text { No }\end{array}$ & $\begin{array}{l}138 \\
931\end{array}$ & $\begin{array}{r}43(31) \\
216(23)\end{array}$ & $1.5(0.99$ to 2.3$)$ \\
\hline Bending forwards in an uncomfortable position $\geqslant 15$ minutes & $\begin{array}{l}\text { Yes } \\
\text { No }\end{array}$ & $\begin{array}{l}288 \\
772\end{array}$ & $\begin{array}{r}77(27) \\
180(23)\end{array}$ & $1.1(0.8$ to 1.6$)$ \\
\hline Squatting $\geqslant 15$ minutes & $\begin{array}{l}\text { Yes } \\
\text { No }\end{array}$ & $\begin{array}{l}151 \\
905\end{array}$ & $\begin{array}{r}46(30) \\
211(23)\end{array}$ & 1.5 (0.98 to 2.2$)$ \\
\hline
\end{tabular}


Table 5 Dose-risk relation between the number of main risk factors and low back pain

\begin{tabular}{lcclc}
\hline $\begin{array}{l}\text { Exposures } \\
n\end{array}$ & Total & $\begin{array}{l}\text { Low back pain } \\
n(\%)\end{array}$ & $\begin{array}{l}\text { Adjusted for age and sex } \\
\text { OR }(95 \% \text { CI })\end{array}$ & $\begin{array}{l}\text { Test for trend, } \\
\chi^{2} \text { p value }\end{array}$ \\
\hline 0 & 745 & $157(21)$ & 1.0 & $15.0, \mathrm{p}<0.005$ \\
1 & 180 & $53(29)$ & $1.5(1.04$ to 2.3$)$ & \\
2 & 82 & $30(37)$ & $2.0(1.2$ to 3.3$)$ & \\
3 & 26 & $13(50)$ & $3.3(1.4$ to 7.7$)$ & \\
\hline
\end{tabular}

${ }^{\star}$ Lifting $>25 \mathrm{lb}(11 \mathrm{~kg})$ with one hand, lifting $>50 \mathrm{lb}(23 \mathrm{~kg})$ with two hands, carrying $>50 \mathrm{lb}(23$ $\mathrm{kg}$ ) on one shoulder.

Table 6 Relations between occupational load and shoulder pain

\begin{tabular}{|c|c|c|c|c|}
\hline Exposure & & Total & $\begin{array}{l}\text { Shoulder pain } \\
n(\%)\end{array}$ & $\begin{array}{l}\text { Adjusted for age } \\
\text { and sex } \\
\text { OR }(95 \% \text { CI) }\end{array}$ \\
\hline Lifting $>25 \mathrm{lb}(11 \mathrm{~kg})$ with one hand: & $\begin{array}{l}\text { Yes } \\
\text { No }\end{array}$ & $\begin{array}{l}228 \\
832\end{array}$ & $\begin{array}{r}71(31) \\
148(18)\end{array}$ & $1.8(1.3$ to 2.6$)$ \\
\hline Lifting $>50 \mathrm{lb}(23 \mathrm{~kg})$ with two hands & $\begin{array}{l}\text { Yes } \\
\text { No }\end{array}$ & $\begin{array}{l}103 \\
950\end{array}$ & $\begin{array}{r}41(34) \\
176(19)\end{array}$ & 2.7 (1.7 to 4.2$)$ \\
\hline Carrying $>50 \mathrm{lb}(23 \mathrm{~kg})$ on one shoulder & $\begin{array}{l}\text { Yes } \\
\text { No }\end{array}$ & $\begin{array}{l}100 \\
962\end{array}$ & $\begin{array}{r}45(45) \\
173(18)\end{array}$ & $3.1(1.9$ to 4.8$)$ \\
\hline Lift $>25 \mathrm{lb}(11 \mathrm{~kg})$ at or above shoulder level & $\begin{array}{l}\text { Yes } \\
\text { No }\end{array}$ & $\begin{array}{l}146 \\
911\end{array}$ & $\begin{array}{r}50(34) \\
162(18)\end{array}$ & $2.0(1.3$ to 3.0$)$ \\
\hline Pulling $>50 \mathrm{lb}(23 \mathrm{~kg})$ & $\begin{array}{l}\text { Yes } \\
\text { No }\end{array}$ & $\begin{array}{l}168 \\
892\end{array}$ & $\begin{array}{r}45(27) \\
170(19)\end{array}$ & $1.6(1.1$ to 2.4$)$ \\
\hline Pushing >100 lb (45 kg) & $\begin{array}{l}\text { Yes } \\
\text { No }\end{array}$ & $\begin{array}{l}136 \\
921\end{array}$ & $\begin{array}{r}37(27) \\
177(19)\end{array}$ & $1.5(0.97$ to 2.4$)$ \\
\hline Driving $\geqslant 15$ minutes & $\begin{array}{l}\text { Yes } \\
\text { No }\end{array}$ & $\begin{array}{l}101 \\
976\end{array}$ & $\begin{array}{r}18(18) \\
202(21)\end{array}$ & $0.8(0.4$ to 1.3$)$ \\
\hline Stretching down below knee level $\geqslant 15$ minutes & $\begin{array}{l}\text { Yes } \\
\text { No }\end{array}$ & $\begin{array}{l}138 \\
931\end{array}$ & $\begin{array}{r}37(27) \\
182(20)\end{array}$ & $1.4(0.9$ to 2.1$)$ \\
\hline $\begin{array}{l}\text { Bending forwards in an uncomfortable position } \\
\geqslant 15 \text { minutes }\end{array}$ & $\begin{array}{l}\text { Yes } \\
\text { No }\end{array}$ & $\begin{array}{l}288 \\
772\end{array}$ & $\begin{array}{r}77(27) \\
144(19)\end{array}$ & $1.6(1.2$ to 2.2$)$ \\
\hline Hands above shoulder level $\geqslant 15$ minutes & $\begin{array}{l}\text { Yes } \\
\text { No }\end{array}$ & $\begin{array}{l}223 \\
839\end{array}$ & $\begin{array}{r}54(24) \\
163(19)\end{array}$ & $1.3(0.9$ to 1.8$)$ \\
\hline Repetitive arm movements $\geqslant 2 \mathrm{~h}$ & $\begin{array}{l}\text { Yes } \\
\text { No }\end{array}$ & $\begin{array}{l}291 \\
774\end{array}$ & $\begin{array}{r}65(22) \\
152(20)\end{array}$ & $1.2(0.9$ to 1.7$)$ \\
\hline
\end{tabular}

Table 7 Dose-risk relation between the number of main risk factors and shoulder pain

\begin{tabular}{lllll}
\hline $\begin{array}{l}\text { Exposures } \\
n\end{array}$ & Total & $\begin{array}{l}\text { Shoulder pain } \\
n(\%)\end{array}$ & $\begin{array}{l}\text { Adjusted for age and sex } \\
\text { OR }(95 \% \text { CI })\end{array}$ & $\begin{array}{l}\text { Test for trend, } \\
\chi^{2} \text { p value }\end{array}$ \\
\hline 0 & 489 & $67(14)$ & 1.0 & $31.8, \mathrm{p}<0.005$ \\
1 & 252 & $52(21)$ & $1.6(1.03$ to 2.4$)$ & \\
2 & 112 & $32(29)$ & $2.4(1.4$ to 3.9$)$ & \\
3 & 78 & $26(33)$ & $2.8(1.6$ to 4.8$)$ & \\
$\geqslant 4$ & 59 & $27(46)$ & $4.3(2.4$ to 7.9$)$ &
\end{tabular}

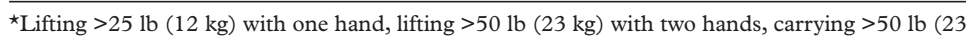
$\mathrm{kg}$ ) on one shoulder, lifting $>25 \mathrm{lb}(12 \mathrm{~kg})$ at or above shoulder level, pulling $>50 \mathrm{lb}(23 \mathrm{~kg})$ and bending forwards in an uncomfortable position for at least 15 minutes.

Table 8 Relations between occupational load and knee pain

\begin{tabular}{|c|c|c|c|c|}
\hline Exposure & & Total & $\begin{array}{l}\text { Knee pain } \\
n(\%)\end{array}$ & $\begin{array}{l}\text { Adjusted for age } \\
\text { and sex } \\
\text { OR }(95 \% \text { CI) }\end{array}$ \\
\hline Lifting $>25 \mathrm{lb}(11 \mathrm{~kg})$ with one hand: & $\begin{array}{l}\text { Yes } \\
\text { No }\end{array}$ & $\begin{array}{l}228 \\
832\end{array}$ & $\begin{array}{r}68(30) \\
147(18)\end{array}$ & $1.7(1.2$ to 2.4$)$ \\
\hline Lifting $>50 \mathrm{lb}(23 \mathrm{~kg})$ with two hands & $\begin{array}{l}\text { Yes } \\
\text { No }\end{array}$ & $\begin{array}{l}103 \\
950\end{array}$ & $\begin{array}{r}30(29) \\
189(20)\end{array}$ & $1.6(1.01$ to 2.6$)$ \\
\hline Carrying $>50 \mathrm{lb}(23 \mathrm{~kg})$ on one shoulder & $\begin{array}{l}\text { Yes } \\
\text { No }\end{array}$ & $\begin{array}{l}100 \\
962\end{array}$ & $\begin{array}{r}46(46) \\
175(18)\end{array}$ & 3.5 (2.2 to 5.5$)$ \\
\hline Lift $>25 \mathrm{lb}(11 \mathrm{~kg})$ at or above shoulder level & $\begin{array}{l}\text { Yes } \\
\text { No }\end{array}$ & $\begin{array}{l}146 \\
911\end{array}$ & $\begin{array}{r}49(34) \\
167(18)\end{array}$ & $1.9(1.3$ to 2.9$)$ \\
\hline Pulling $>50 \mathrm{lb}(23 \mathrm{~kg})$ & $\begin{array}{l}\text { Yes } \\
\text { No }\end{array}$ & $\begin{array}{l}168 \\
892\end{array}$ & $\begin{array}{r}44(26) \\
174(20)\end{array}$ & $1.5(1.04$ to 2.3$)$ \\
\hline Pushing $>100 \mathrm{lb}(45 \mathrm{~kg})$ & $\begin{array}{l}\text { Yes } \\
\text { No }\end{array}$ & $\begin{array}{l}136 \\
921\end{array}$ & $\begin{array}{r}32(24) \\
186(20)\end{array}$ & $1.2(0.8$ to 1.9$)$ \\
\hline Driving $\geqslant 15$ minutes & $\begin{array}{l}\text { Yes } \\
\text { No }\end{array}$ & $\begin{array}{l}101 \\
976\end{array}$ & $\begin{array}{r}21(21) \\
201(21)\end{array}$ & $1.0(0.6$ to 1.7$)$ \\
\hline Kneeling $\geqslant 15$ minutes & $\begin{array}{l}\text { Yes } \\
\text { No }\end{array}$ & $\begin{array}{l}158 \\
916\end{array}$ & $\begin{array}{r}45(28) \\
176(19)\end{array}$ & $1.8(1.2$ to 2.6$)$ \\
\hline Squatting $\geqslant 15$ minutes & $\begin{array}{l}\text { Yes } \\
\text { No }\end{array}$ & $\begin{array}{l}151 \\
905\end{array}$ & $\begin{array}{r}35(23) \\
184(20)\end{array}$ & $1.3(0.8$ to 1.9$)$ \\
\hline
\end{tabular}

2.3)), as was the relation with carrying more than $50 \mathrm{lb}(23 \mathrm{~kg}$ ) on one shoulder (OR 1.3 (95\% CI 1.7 to 2.2$)$ ). There were similar results for knee pain. The relations with lifting more than $25 \mathrm{lb}(11 \mathrm{~kg})$ with one hand (OR 1.3 ( $95 \%$ CI 0.9 to 2.0$)$ ), lifting more than $50 \mathrm{lb}$ $(23 \mathrm{~kg})$ with two hands (OR $1.2(95 \%$ CI 0.7 to 1.9)), and carrying more than $50 \mathrm{lb}(23 \mathrm{~kg})$ on one shoulder (OR 2.2 (95\% CI 1.3 to 3.7)) were all reduced after adjusting for occupational group.

Finally we investigated the specificity of the relations found by considering the frequency of co-occurrence of pain at the sites investigated. Specifically, as broadly the same risk factors emerged for back, shoulder, and knee pain, we postulated that these factors would be more important in people with multiple pain. Thus $55 \%, 62 \%$, and $59 \%$ respectively of people reporting back, shoulder, or knee pain, reported pain in at least one of the other two sites. We then examined the relation between the three main factors: lifting more than $25 \mathrm{lb}$ $(11 \mathrm{~kg}$ ) with one hand, lifting more than $50 \mathrm{lb}$ (23 kg) with two hands, and carrying more than $50 \mathrm{lb}(23 \mathrm{~kg})$ on one shoulder, and the development of pain at two or more of these sites. The results showed stronger associations: lifting more than $25 \mathrm{lb}(11 \mathrm{~kg})$ with one hand OR 2.2 (95\% CI 1.5 to 3.3), lifting more than $50 \mathrm{lb}(23 \mathrm{~kg})$ with two hands OR $2.6(95 \%$ CI 1.6 to 4.4 ) and carrying more than $50 \mathrm{lb}$ on one shoulder OR 5.6 (95\% CI 3.3 to 9.7). By contrast, few of these relations persisted when the groups with pain at only one of these sites were analysed.

\section{Discussion}

Even at an early stage of employment, there is evidence of a relation between mechanical factors and regional musculoskeletal pain affecting the low back, shoulder, and knee and some evidence of an influence of repetitive wrist movements on wrist and forearm pain. The individual associations were modest with no great specificity with the exception of forearm pain. This lack of specificity is highlighted by the associations being greatest in those with more than one site of pain. For each area of pain, the more mechanical factors that the person was exposed to, the greater were the ORs. Despite most of these people having only worked in this employment for a few months and the study participants being young, and therefore any effect may be diluted, those exposed to all of the most pertinent mechanical factors had a fourfold chance of having developed knee pain and shoulder pain and a threefold chance of having developed low back pain. Pain was more common among men than women, which is opposite to most reports. ${ }^{21}$ This discrepancy reflects differences in levels of exposure to physical job demands between men and women in this study. Men were exposed to higher levels of mechanical exposures than women.

Lifting weights with one or both hands and carrying weights on one shoulder were associated with pain at all anatomical sites with the exception of wrist and forearm pain. There was 
Table 9 Dose-risk relation between the number of main risk factors and knee pain

\begin{tabular}{lccll}
\hline $\begin{array}{l}\text { Exposures* } \\
n\end{array}$ & Total & $\begin{array}{l}\text { Knee pain } \\
n(\%)\end{array}$ & $\begin{array}{l}\text { Adjusted for age } \\
\text { and sex } \\
\text { OR }(95 \% \text { CI) }\end{array}$ & $\begin{array}{l}\text { Test for trend, } \\
\chi^{2} p \text { value }\end{array}$ \\
\hline 0 & 639 & $102(16)$ & 1.0 & $21.6, \mathrm{p}<0.005$ \\
1 & 179 & $37(21)$ & $1.2(0.8$ to 1.9$)$ & \\
2 & 102 & $32(31)$ & $2.1(1.3$ to 3.5$)$ & \\
3 & 63 & $20(32)$ & $2.1(1.2$ to 3.9$)$ & \\
$\geqslant 4$ & 32 & $15(47)$ & $4.4(2.0$ to 9.4$)$ & \\
\hline
\end{tabular}

${ }^{\star}$ Lifting $>25 \mathrm{lb}(11 \mathrm{~kg})$ with one hand, lifting $>50 \mathrm{lb}(23 \mathrm{~kg})$ with two hands, carrying $>50 \mathrm{lb}(23$ $\mathrm{kg}$ ) on one shoulder, lifting $>25 \mathrm{lb}(11 \mathrm{~kg})$ at or above shoulder level, and kneeling for at least 15 minutes.

Table 10 Relations between occupational load and pain of the wrist or forearm or both

\begin{tabular}{|c|c|c|c|c|}
\hline Exposure & & Total & $\begin{array}{l}\text { Wrist or } \\
\text { forearm pain } \\
n(\%)\end{array}$ & $\begin{array}{l}\text { Adjusted for age } \\
\text { and sex } \\
\text { OR }(95 \% \text { CI })\end{array}$ \\
\hline Lifting $>25 \mathrm{lb}(11 \mathrm{~kg})$ with one hand & $\begin{array}{l}\text { Yes } \\
\text { No }\end{array}$ & $\begin{array}{l}228 \\
832\end{array}$ & $\begin{array}{l}23(10) \\
68(8)\end{array}$ & $1.2(0.7$ to 2.0$)$ \\
\hline Lifting $>50 \mathrm{lb}(23 \mathrm{~kg})$ with two hands & $\begin{array}{l}\text { Yes } \\
\text { No }\end{array}$ & $\begin{array}{l}103 \\
950\end{array}$ & $\begin{array}{l}11(11) \\
80(8)\end{array}$ & $1.4(0.7$ to 2.8$)$ \\
\hline Carrying $>50 \mathrm{lb}(23 \mathrm{~kg})$ on one shoulder & $\begin{array}{l}\text { Yes } \\
\text { No }\end{array}$ & $\begin{array}{l}100 \\
962\end{array}$ & $\begin{array}{r}8(8) \\
82(9)\end{array}$ & $1.0(0.4$ to 2.1$)$ \\
\hline Lift $>25 \mathrm{lb}(11 \mathrm{~kg})$ at or above shoulder level & $\begin{array}{l}\text { Yes } \\
\text { No }\end{array}$ & $\begin{array}{l}146 \\
911\end{array}$ & $\begin{array}{l}16(11) \\
72(8)\end{array}$ & $1.4(0.8$ to 2.5$)$ \\
\hline Pulling $>50 \mathrm{lb}(23 \mathrm{~kg})$ & $\begin{array}{l}\text { Yes } \\
\text { No }\end{array}$ & $\begin{array}{l}168 \\
892\end{array}$ & $\begin{array}{l}17(10) \\
74(8)\end{array}$ & $1.3(0.7$ to 2.3$)$ \\
\hline Pushing $>100 \mathrm{lb}(45 \mathrm{~kg})$ & $\begin{array}{l}\text { Yes } \\
\text { No }\end{array}$ & $\begin{array}{l}136 \\
921\end{array}$ & $\begin{array}{r}8(6) \\
83(9)\end{array}$ & $0.6(0.3$ to 1.3$)$ \\
\hline Repetitive wrist movements $\geqslant 4 \mathrm{~h}$ & $\begin{array}{l}\text { Yes } \\
\text { No }\end{array}$ & $\begin{array}{l}158 \\
895\end{array}$ & $\begin{array}{l}22(14) \\
69(8)\end{array}$ & $1.8(1.04$ to 3.1$)$ \\
\hline
\end{tabular}

little evidence of relations with posture: bending forwards in an uncomfortable position was associated with shoulder pain and kneeling was associated with knee pain. Repetitive movements of the upper limb were not associated with pain at any of the sites of interest except wrist and forearm pain.

One of the prevailing strengths of the current study is that it has attempted to overcome one of the main aspects of the healthy worker effect-namely, that those who have pain are more likely to leave work thereby leaving behind a healthy workforce. The subjects in this study had recently started employment and none had left due to musculoskeletal pains. No other study has considered the influence of work related factors on musculoskeletal pain among newly employed workers.

The study was also conducted among a diverse range of occupations. This enabled the study of subjects exposed to different levels of mechanical factors in different settings. Most studies have focused on a single occupational group. Only a few authors have considered several occupational groups. ${ }^{4}$ These are usually very similar occupations but a few studies have looked at diverse groups, for example, homecare workers and municipal workers. ${ }^{152}$

The study also used a standardised measurement of exposure across several occupational groups. ${ }^{20}$ Very few studies have used validated measures to study postures, repetitive movements, and manual handling and those that have ${ }^{23} 24$ tended to report that subjects were able to discriminate between exposure and non-exposure but were unable to measure exposure in more detail. Others have reported that postures are accurately recalled whereas more active tasks-such as repetitive movement and manual handling activities, are less accurately reported..$^{25}$ The questionnaire used in our study has been reported to be accurate for assessing self reports for all three aspects: postures, repetitive movements, and manual handling activities. ${ }^{20}$ Agreement was assessed with measures of sensitivity and specificity. The lowest agreement was found for repetitive movements.

Furthermore, the study considered several regions of pain and was therefore able to make genuine comparisons between findings and avoid the problems of comparing results from different studies which have used diverse methods to examine risks associated with individual regions of pain. With the exception of wrist and forearm pain, there were similar mechanical factors associated with low back pain, shoulder pain, and knee pain. This is partly explained by the fact that many subjects had pain in more than one of the regions of interest (results not shown). Only a few other studies have considered pain at many sites, ${ }^{16}{ }^{26}$ most have focused on a single site of pain or upper limb pain in general.

There are, however, several important methodological concerns that need to be considered. Firstly, workers were asked to report mechanical activities during their last working day. Although this day may not be typical, such an approach is likely to generate more accurate replies than requests about an average day. We attempted in the questionnaire to estimate the representativeness of the study day. Fifty three per cent reported that this day was as physically demanding as usual, whereas $29 \%$ reported that it was less physically demanding and $18 \%$ reported that it was more physically demanding. This suggests no evidence of systematic bias but the existence of some misclassification which may result in an underestimation of the effect of exposures on outcomes.

Secondly, the outcome used was self reported pain and no clinical validation was attempted. The pathological cause of musculoskeletal pain is often unclear and the factors which determine whether a person receives a diagnosis are arbitrary. Thus, such reports of symptoms may be a more meaningful measure of the prevalence of musculoskeletal disorders. ${ }^{27}$ Subjects may indeed report pain which is of little consequence in terms of disability but perception of pain and related disability are the factors which most likely lead to absence from work and work disability and therefore these indicators of musculoskeletal problems may be more pertinent. The study also relied on a pain drawing or body manikin. This approach has been used in many studies as an instrument to record self reported pain and has been reported as a reliable measure. ${ }^{28}$ Studies that have used pain drawings have published their construct validity. ${ }^{29}{ }^{30}$ Subjects may indeed report pain which is of little consequence in terms of disability. None the less the ascertainment of musculoskeletal disorders in this study did rely on a definition of low stringency. Despite this, some strong relations between mechanical factors and regional pain were identified in the current study. Stronger associations may have been found if severity of 
pain had been taken into account. On the other hand, severity may be associated with other factors, such as psychological wellbeing. Conversely, as ORs were used to analyse the data rather than prevalence ratios, the associations may be exaggerated because ORs will tend to overestimate the strength of any associations when the prevalence of the outcome is relatively common (at least $10 \%$ ). Alternative analyses were conducted to calculate prevalence ratios, and with few exceptions, although the observed associations were reduced, they retained significance.

Thirdly, it is important to consider the possible role of confounding. Confounding occurs when the relation between two factors can be explained by the fact that a third factor is associated with the risk factor and is independently associated with the outcome. One important concern is that unmeasured job related factors might explain the occurrence of pain which may be specific to some occupational setting. We attempted to consider this by adjusting for occupational group. As discussed many of the relations were attenuated. Although these results may be explained by confounding, an alternative explanation is that some of the exposures were concentrated in specific groups. For example, carrying heavy items on one shoulder was mainly carried out by the army infantry who in turn complained most of pain in the areas studied. Indeed 54\% of those subjects who reported this activity were from army infantry and $23 \%$ of those with shoulder pain were army infantry. As occupational group is a measure of many factors, some of which are unknown, we were unable to assess the role of particular features of the working environment which are associated with pain. Importantly many of the associations, however, were not explained by group.

One important group of factors which may act as confounders is the psychosocial working environment, including factors such as job demands, control, social support, and job satisfaction. In recent years there has been much interest in this aspect of the occupational setting and indeed, it has been reported that these factors are related to musculoskeletal pain. ${ }^{31}$ As such factors may also be associated with mechanical factors (for example, those with physically demanding work may have little control over their job), work related psychosocial factors were treated as potential confounders in the current study. None of the psychosocial factors had any impact on the relations between mechanical factors and pain. This lack of effect may be explained by the fact that very few subjects reported adverse psychosocial factors at this early stage of their employment.

Fourthly, there may be other factors which might explain the subject's pain. For example, physical activity outside the workplace might be responsible for musculoskeletal injury. As the study group is young and many carried out physically demanding jobs, it is likely that subjects may be physically active during their leisure time. The authors attempted to assess physical activity and found that they were unable to discriminate between subjects as most were involved in sports or activities during their non-working time which were physically strenuous.

Fifthly, as the study is cross sectional and both exposures and outcomes are reported at the same time, it is difficult to exclude the possibility of recall bias-namely, that those who have symptoms may recall occupational exposures in a different way to those who do not. By asking subjects to recall exposures relating to the last working day rather than a typical day this may reduce the possibility of recall bias. Furthermore, subjects were blinded to the hypothesis of the study: no mention of the specific outcomes was made on the front page of the questionnaire or in any promotion of the study, information relating to exposures was gathered before data on outcomes and details of other health outcomes (non-pain: not of primary interest to the authors) were collected.

In a cross sectional study associations can be established but no conclusions on the temporality of the relation can be made. However, in the current study it is more likely that specific mechanical exposures preceded pain rather than that earlier pain led to selection for specific occupations as positive rather than negative associations were identified. No data were collected about pain which occurred before the start of the current job. Therefore it is not possible to distinguish between those subjects who experienced their first ever episode of pain and those for whom pain was exacerbated. Details of past pain are difficult to measure retrospectively as such data are likely to be influenced by any current pain.

This study has shown that mechanical factors in the short term are associated with regional pain. By studying new workers, all those who may have subsequently left due to musculoskeletal pain have been included. On the other hand, newly employed workers may be healthier than established workers due to several factors including current or recent training relating to working postures and manual handling techniques, the young age of the workers whose musculoskeletal system may be less prone to damage compared with that of older workers, and due to the healthy hire effect-namely, that unfit people may be denied access to a new workforce.

This study was supported by the British Occupational Health Research Foundation and the Arthritis Research Campaign. We thank all the occupational groups which took part, including all the subjects and those people who allowed us access to each workforce.

1 Bernard BP. Musculoskeletal disorders and workplace factors. A critical review of epidemiologic evidence of work-related musculoskeletal disorders of the neck, upper extremity, and low back. Cincinnati: National Institute for Occupational Safety and Health, 1997.

2 Hagberg M, Wegman DH. Prevalence rates and odds ratios of shoulder-neck diseases in different occupational groups. Br f Ind Med 1987;44:602-10.

3 Hult L. Cervical, dorsal and lumbar spinal syndromes. Acta Orthop Scand 1954:(suppl 17).

4 Riihimäki H, Tola S, Videman T, et al. Low-back pain and occupation. A cross-sectional questionnaire study of men in machine operating, dynamic physical work, and in machine operating, dynamic phys

5 Nordander C, Ohlsson K, Balogh I, et al. Fish processing work: the impact of two sex dependent exposure profiles on musculoskeletal health. Occup Environ Med 1999;56:256-64. 
6 Heuer $\mathrm{H}$, Klimmer F, Kylian $\mathrm{H}$, et al. Musculoskeletal problems in bricklayers as a function of length of employment: the role of secondary selec

7 Macfarlane GJ, Thomas E, Papageorgiou AC, et al. Employment and physical work activities as predictors of future low back pain. Spine 1997;22:1143-9.

8 Linton SJ. Risk factors for neck and back pain in a working population in Sweden. Work and Stress 1990;4:41-9.

9 Skovron ML. Epidemiology of low back pain. Bailliere's Clin Rheum 1992;6:559-73.

10 Sakakibara H, Miyao M, Kondo T, et al. Overhead work and shoulder-neck pain in orchard farmers harvesting pears and apples. Ergonomics 1995;38:700-6.

11 Buchbinder R, Goel V, Bombardier C, et al. Classification systems of soft tissue disorders of the neck and upper limb: do they satisfy methodological guidelines? F Clin Epidemiol 1996;49:141-9.

$12 \mathrm{Xu}$ Y, Bach E, Orhede E. Work environment and low back pain: the influence of occupational activities. Occup Environ pain: the influence of occur

13 Walsh K, Cruddas M, Coggon D. Interaction of height and mechanical loading of the spine in the development of lowback pain $S$ cand $\mathscr{F}$ Work Environ $H$ ealth 1

14 Svensson HO, Andersson GB. Low back pain in 40 to 47 year old men: work history and work environment factors. Spine 1983;8:272-6.

15 Carter JB, Banister EW. Musculoskeletal problems in VDT work: a review. Ergonomics 1994;37:1623-48.

16 Sobti A, Cooper C, Inskip H, et al. Occupational physical activity and long-term risk of musculoskeletal symptoms: a national survey of post office pensioners. Am 7 Ind $\mathrm{Med}$ 1997;32:76-83

17 Schierhout GH, Myers JE, Bridger RS. Work-related musculoskeletal disorders and ergonomic stressors in the South African workforce. Occup Environ Med 1995;52:46-50.

18 Bergenudd $\mathrm{H}$, Lindgarde F, Nilsson B, et al. Shoulder pain in middle age. A study of prevalence and relation to occuin middle age. A study of prevalence and relation to occupational workload

19 Blaxter M. Health and lifestyles. London: Tavistock, Routledge, 1990.
20 Pope DP, Silman AJ, Cherry NM, et al. Validity of a self completed questionnaire measuring the physical demands of work. Scand F Work Environ Health 1998;24:376-85.

21 Skovron ML, Szpalski M, Nordin M, et al. Sociocultural factors and back pain: a population-based study in Belgian adults. Spine 1994;19:21-8.

22 Johansson JA. Psychosocial work factors, physical work load and associated musculoskeletal symptoms among home care workers. Scand f Psychol 1995;36:113-29.

23 Wiktorin C, Karlqvist L, Winkel J, et al. Validity of self-reported exposures to work postures and manual materials handling. Scand f Work Environ Health 1993;19: 208-14.

24 Viikari-Juntura E, Rauas S, Martikainen R, et al. Validity of self-reported physical work load in epidemiological studies on musculoskeletal disorders. Scand $\mathcal{F}$ Work Environ Health 1996;22:251-9.

25 Baty D, Buckle PW, Stubbs DA. Recording by direct observation, questionnaire assessment and instrumentation: a comparison based on a recent field study. In: Corbett N, Wilson J, Manenica I, eds. The ergonomics of working postures. London: Taylor and Francis, 1986.

26 Skov T, Borg V, Orhede E. Psychosocial and physical risk factors for musculoskeletal disorders of the neck, shoulders. and lower back in salespeople. Occup Environ Med 1996;53:351-6.

27 Schierhout GH, Myers JE. Is self-reported pain an appropriate outcome measure in ergonomic-epidemiologic studies of work-related musculoskeletal disorders? $\mathrm{Am} \mathcal{F}$ Ind Med 1996;30:93-8.

28 Margolis RB, Chibnall JT, Tait RC. Test-retest reliability of the pain drawing instrument. Pain 1988;33:49-51.

29 Pope DP, Croft PR, Pritchard CM, et al. Occupational factors related to shoulder pain and disability. Occup Environ Med 1997;54:316-21.

30 Thomas E, Silman AJ, Papageorgiou AC, et al. Association between measures of spinal mobility and low back pain. An analysis of new attenders in primary care. Spine 1998;23: analysis

31 Bongers PM, de Winter CR, Kompier MAJ, et al. Psychosocial factors at work and musculoskeletal disease. Scand $\mathcal{F}$ Work Environ Health 1993:19:297-312.

\section{Rejected manuscripts}

Authors whose submitted articles are rejected will be advised of the decision and one copy of the article, together with any reviewer's comments, will be returned to them. The
Fournal will destroy remaining copies of the article but correspondence and reviewers' comments will be kept. 